\title{
Emergency contraception, a study on knowledge, attitude and practice among gynecologists
}

\author{
Sunil Kumar K. S.*, Suchith Hoblidar
}

Department of Obstetrics and Gynecology, SDM College of Medical Sciences and Hospital, Sattur. Dharwad. Karnataka, India

Received: 15 October 2015

Revised: 16 October 2015

Accepted: 15 December 2015

\section{*Correspondence:}

Dr. Sunil Kumar K S,

E-mail: drsuneelks@gmail.com

Copyright: () the author(s), publisher and licensee Medip Academy. This is an open-access article distributed under the terms of the Creative Commons Attribution Non-Commercial License, which permits unrestricted non-commercial use, distribution, and reproduction in any medium, provided the original work is properly cited.

\begin{abstract}
Background: The present study was conducted to study the knowledge, attitude and practice of emergency contraception (EC) among the practicing gynecologists.

Methods: A cross-sectional study was carried out with the help of predesigned questionnaire among the members of local obstetrics and gynecological society. The questionnaire included questions regarding basic knowledge, misconception and attitude towards use of emergency contraception.

Results: Results were analyzed using 124 fully completed questionnaires. Majority of them were female gynecologists (72\%). About $84 \%$ were not offering EC routinely nor did they advice the same to their clients. All the participants were aware of levonorgestrel (LNG) being used for EC. Only about $64 \%$ of them answered correctly about the dosage and timing of initiation of EC. About $12 \%$ of the participant gynecologists believed that EC is a form of abortion. Fifty eight percent of the respondents believed that it promotes the irresponsible and promiscuous behavior in the clients and $60 \%$ felt that it is targeted mainly at unmarried adolescents and may undermine the parental authority and community morals, which show a strong misconception even among the gynecologists. About $54 \%$ believed that women/couples may stop using the regular contraception if it is easily available. About $10 \%$ felt that it is not safe to use EC.

Conclusions: There is a great paucity of knowledge regarding the use of EC not only among the general public and clients, but also among the service providers and health professionals. This study concluded that there is lack of awareness and certain misconceptions about the use of EC even among the gynecologists, which has resulted in underutilization of EC. There is an urgent need for sensitizing all sections of people about EC through appropriate programs for curbing the population.
\end{abstract}

Keywords: Emergency contraception, Levonorgestrel, Gynecologists, Knowledge, Attitude, Practice

\section{INTRODUCTION}

India is emerging as the most populous country in the world and with a fertility rate of $2.4 \%$, our population would be 1.4 billion by $2026 .^{1}$ This exponential growth of population is posing a threat to our resources which could be prevented by the elaborate use of contraception especially emergency contraception as it targets unwanted and unplanned pregnancies.

Emergency contraception (EC) is considered a second chance contraceptive method that can be used within 72 hours of unprotected intercourse or contraceptive failure 
and plays an important role as a back-up for other regular methods of contraception. ${ }^{2}$ Various methods are available for this purpose, most popular being oral progestin-only pill, containing levenorgestrel. Antiprogestin ulipristal acetate or use of combined oral contraceptive pill is also effective. A copper intrauterine device is the most effective form of emergency contraception for medically eligible women and may prevent pregnancy if inserted up to 5 days after unprotected coitus. Levonorgestel emergency contraception pill (LNG-EC) is well tolerated and efficacy is such that $74 \%$ of pregnancies could be prevented with a failure rate of $1 \%$ and with minimal side effects. $^{2}$ The Drug Controller general of India approved levenorgesrel for EC in the year 2001 and EC pills have been introduced through National Family Welfare Programme in 2003. ${ }^{3}$ LNG-EC has been supplied free of cost by government of India (GOI) ${ }^{4,5}$ and since 2005 it has been made available over-the-counter in India. ${ }^{6}$ The usage of LNG-EC has marginally improved since then but hasn't been sufficiently adequate. This is mainly because doctors as well as clients are prejudiced against use of EC for various reasons.

It appears that EC not being popular and not being prescribed regularly by the gynecologists. Hence we conducted this study to know the knowledge, the attitude and practice of use of EC among obstetricians and gynecologists as they play an important role in transferring the information to the target population.

\section{METHODS}

We conducted a cross-sectional study among practicing obstetricians and gynecologists who had gathered for a scientific session arranged by the local OBG society. All the participants were informed about the nature and the purpose of the study. We used predesigned questionnaires to collect the information. Completed questionnaires were collected from the participants at the end of the scientific session which lasted for one and half hours. We included questions regarding the prescription of EC, knowledge of various methods available for EC, mechanism of action of the various methods, side effects, dosage, failure rates, and trade names of the available formulations. Also we included questions that whether EC is available over the counter without doctor's prescription, if client's written consent was needed. We tried to know about the misconceptions by asking whether EC promoted promiscuous behavior, whether it undermines parental authority among adolescents and whether it affect the use of other regular contraceptions. Data collection and analysis was carried out with Microsoft Excel XP and presented as percentages and proportions.

\section{RESULTS}

Results were analysed using 124 fully completed questionnaires. Majority of them were female gynecologists (72\%). Experience in the field of gynecology was less than 5 years for $34 \%$, up to 10 years for $43 \%$ and $23 \%$ had experience more than 10 years. Most of them belonged to age group of 35-40 years, with median age being 37.6 years. Table 1 shows the questionnaires and the answers given by the participants.

Table 1: Questions on knowledge and attitude about Emergency Contraception.

\begin{tabular}{|c|c|c|c|}
\hline Questions & Yes & No & $\begin{array}{l}\text { Don't } \\
\text { know }\end{array}$ \\
\hline $\begin{array}{l}\text { Is EC* globally accepted } \\
\text { method of contraception }\end{array}$ & $97 \%$ & 0 & $3 \%$ \\
\hline $\begin{array}{l}\text { Is emergency contraception } \\
\text { a form of abortion }\end{array}$ & $12 \%$ & $80 \%$ & $8 \%$ \\
\hline $\begin{array}{l}\text { Is EC better than regular } \\
\text { contraception }\end{array}$ & $13 \%$ & $87 \%$ & 0 \\
\hline $\begin{array}{l}\text { Is written informed consent } \\
\text { is required for use of LNG- } \\
\mathrm{EC} \dagger\end{array}$ & $14 \%$ & $76 \%$ & 0 \\
\hline $\begin{array}{l}\text { Has EC been approved for } \\
\text { use in India }\end{array}$ & $92 \%$ & $7 \%$ & $1 \%$ \\
\hline $\begin{array}{l}\text { Is EC available free of cost } \\
\text { in India }\end{array}$ & $37 \%$ & $63 \%$ & 0 \\
\hline $\begin{array}{l}\text { Is LNG-EC available over } \\
\text { the counter }\end{array}$ & $77 \%$ & $15 \%$ & $8 \%$ \\
\hline $\begin{array}{l}\text { Does LNG-EC adversely } \\
\text { affect pregnancy when it } \\
\text { fails }\end{array}$ & $36 \%$ & $56 \%$ & $8 \%$ \\
\hline $\begin{array}{l}\text { Does LNG-EC harm if taken } \\
\text { during lactation }\end{array}$ & $9 \%$ & $80 \%$ & $11 \%$ \\
\hline $\begin{array}{l}\text { Is it safe to use emergency } \\
\text { contraception }\end{array}$ & $76 \%$ & $10 \%$ & $4 \%$ \\
\hline
\end{tabular}

Values in numbers indicate the percentage

*Emergency Contraception

$\nmid$ Levonorgestrel Emergency contraception

tHuman Immunodeficiency Virus

Although all the participants were aware about the availability of EC in their locality, surprisingly, only $26 \%$ had ever written prescription for their clients seeking EC in the past. The most common method used by them was levonorgestrel (87\%). And Copper T was used as EC by only $13 \%$ of the paricipant gynecologists. Most of the gynecologists agreed that EC is a globally accepted method of contraception which can be prescribed without a written consent or physical examination. About $77 \%$ of the gynecologists were aware that it is available over the counter without prescription. All of them knew that the commonly used EC is levonorgestrel (LNG-EC), but only $64 \%$ of them wrote the correct dosage of levonorgesrel and $83 \%$ of them knew that it has to start within 72 hours of unprotected intercourse. Majority of them opined correctly that EC is not a form of abortion $80 \%$, doesn't cause birth defects in case of failure $56 \%$, and it can be safely used during lactation $80 \%$.

Table 2 shows the misconceptions and attitude towards use of EC. Majority (58\%) of the gynecologists believed that EC promotes promiscuous sexual behavior, which is 
not true. About $53 \%$ of them falsely believed that EC may discourage to use regular methods of contraception. About 90(72.5\%) participants opined that, men would be less willing to use condoms because of the availability of EC, which is not true. Promisingly $60 \%$ gynecologists stated that use of EC doesn't undermine parental authority and community morals among adolescents.

\section{Table 2: Misconceptions and attitude towards use of} emergency contraception.

\begin{tabular}{|llll|}
\hline \multicolumn{1}{|c}{ Questionnaire } & Yes & No & $\begin{array}{l}\text { Don't } \\
\text { know }\end{array}$ \\
\hline $\begin{array}{l}\text { Does EC }{ }^{\#} \text { promotes } \\
\text { promiscuous sexual behaviour }\end{array}$ & $58 \%$ & $35 \%$ & $7 \%$ \\
\hline $\begin{array}{l}\text { Does EC discourage to use } \\
\text { regular methods of } \\
\text { contraception }\end{array}$ & $54 \%$ & $41 \%$ & $5 \%$ \\
\hline $\begin{array}{l}\text { Does men would be less } \\
\text { willing to use condoms } \\
\text { because of the availability of } \\
\text { EC }\end{array}$ & $73 \%$ & $26 \%$ & $1 \%$ \\
\hline $\begin{array}{l}\text { Does the use of EC undermine } \\
\text { parental authority and } \\
\text { community morals among }\end{array}$ & $60 \%$ & $38 \%$ & $2 \%$ \\
\hline \begin{tabular}{l} 
adolescents \\
\hline
\end{tabular}
\end{tabular}

Values in numbers indicate the percentage

"Emergency contraception

\section{DISCUSSION}

Although Emergency Contraception (EC) is proven to be safe and effective, its limited use is of concern. Emergency contraception acts as an emergency measure to prevent pregnancy with an intention to use this opportunity to help the clients in adopting a regular contraceptive. Results from our study shows the increase in the level of awareness of EC among the participant gynaecologists, unlike the study conducted in north India in 2003 where only $84.8 \%$ were aware of EC. ${ }^{7}$ It is very depressing to know that only $26 \%$ of the gynaecologists have ever prescribed EC in the past. Although many of them did not give a valid reason for not prescribing EC frequently, but the most common reason was late presentation by the client. This was in contrast to the study conducted among family medicine providers by Jennifer et al, where $74 \%$ of them had prescribed EC in the past. $^{8}$ In a study by Lawrence et al participant physicians were critical of EC and many of them prescribed only after sexual assault. ${ }^{9}$

Various methods are available for EC, of which commonly used is the oral progestin only pill containing levonorgestrel, which is been approved and chosen as dedicated product in India since 2005. This was known to only $92 \%$ of our participants. A doctor prescription is not needed and is made available over the counter which was known to only two third of our participants (77\%). Currently the government of India is providing free EC pills all over the country through the family welfare programme, only $37 \%$ of our gynaecologists knew this fact. This explains why the uptake of EC is limited in India. Failure rate of EC varies from $0-2.4 \%$ depending upon the method used resulting in $75 \%$ reduction in the risk of unintended pregnancy. None of our participants clearly mentioned when asked about the efficacy, only $15 \%$ of them gave the nearby answer.

The major drawback for use of EC among our participant gynaecologists appears to be certain social misconception around it as suggested by the answers given for questionnaire which is comparable to the study by Lawrence et al, ${ }^{9}$ Oriji VK et al, ${ }^{10}$ and Rosie Burton et al. ${ }^{11}$ On asking whether EC promotes irresponsible and promiscuous sexual behaviour, $58 \%$ of our participants responded affirmatively, but this is not true and there are no data supporting this opinion. ${ }^{12}$ This was in contrast to the study conducted among family medicine providers where only a minority of them believed so. ${ }^{8}$ On the contrary EC can act as a bridge to provide contraceptive information and counselling for using regular methods of contraception. Also it provides an opportunity to give information on prevention of STDs and HIV/AIDS. Promiscuous behaviour is not the result of widespread use of EC. By restricting the use of EC promiscuity can't be abolished. Promiscuity is a behavioural problem which remains unaltered irrespective of the availability of EC and it needs to be tackled by behavioural modifications. Rather lack of awareness of EC in the general public would only increase the number of unwanted pregnancies.

On questioning whether EC is targeted mainly at unmarried adolescents and may undermine parental authority and community morals, a large number of them $(60 \%)$ said no. It is true because, women of all ages, including adolescents may need EC. However, young women with little knowledge and experience are especially at high risk for unwanted pregnancies, and preventing pregnancies in adolescents is a high priority in all countries. ${ }^{12}$

On asking if men would be less willing to use condoms with the availability of EC, $72 \%$ answered affirmatively but this is a strong misconception that EC can be used as a substitute to regular contraceptive. ${ }^{12}$ EC cannot be used to replace regular contraceptive but it serves as a back-up method when a regular contraceptive method has failed. Clients are to be educated that condoms serve dual purpose of preventing pregnancies and preventing transmission of STDs. EC does not protect against STDs. This information has to be given to the clients so also they should be told that repeated use could be harmful and also costlier than regular contraceptive.

This study clearly shows that although knowledge of EC was good, the prejudices among the gynecologists are silent hindrances to prescribing emergency contraception to their clients. Physician gynecologists in the study Lawrence et al believed that, women would use other 
contraceptives less $(27 \%)$, may initiate sex at younger ages $(12 \%)$ and have more sexual partners $(15 \%) .{ }^{9}$ Rather than dealing with an unwanted pregnancy in a single patient, all the health care providers have to understand the long term implications of unwanted pregnancies to our society and the nation at large. Taking the responsible initiative of spreading awareness and promoting EC could be the first step towards reducing unwanted pregnancies and stabilizing our population.

\section{CONCLUSIONS}

Our study has revealed the paucity of knowledge, awareness about EC among gynaecologists. It also revealed that very few have ever used EC because of misconceptions. It has shown that not only the clients but also healthcare providers are prejudiced against its use.

It has known from various studies that Indian women especially in rural areas are at the mercy of their various relatives for deciding the method of contraception. ${ }^{13}$ Being a single pill, EC provides the ease to women to use it without any interference from any of their relatives. By promoting EC we would be empowering women with the right to decide about her fertility. It is the responsibility of the gynaecologists to improve their knowledge, awareness and attitude towards prescribing EC and spread benefits and importance of using EC to their clients.

\section{Funding: No funding sources}

Conflict of interest: None declared

Ethical approval: The study was approved by the Institutional Ethics Committee

\section{REFERENCES}

1. Ministry of Health and Family Welfare. Data from Health and family welfare statistics in India. 2013;48-9. Available at https://nrhmmis.nic.in/PubFWStatistics\%202013/Co mplete\%20Book.pdf Accessed on 14 October 2013.

2. Speroff L, Fritz MA. Clinical gynaecologic endocrinology and infertility. 7th ed. Philadelphia: Lippincott Williams and Wilkins. 2005: 925-27.
3. Puri CP, Hazari K, Kulkarni R. Information, Education and Communication for Emergency Contraception. J Indian Med Assoc. 2006;104:511-4.

4. Mittal S. Introduction of Emergency Contraception in India. J Indian Med Assoc. 2006;104:499-505.

5. Kishore V, Misro MM. Providers knowledge, attitude and dispensing practices of E-pills in government dispensaries of South District in Delhi, India. Indian $\mathrm{J}$ of Community Medicine. 2010;35(1):46-51.

6. Jayalakshmi MS. Editorial on Emergency Contraceptive Pills. J Indian Medical Association. 2006;104:490-91.

7. Tripati R, Rathore AM, Sachdeva J. Emergency Contraception-Knowledge, attitude and practices among health care providers in North India. Journal of Obstetric and Gynaecological Research. 2003;29(3):142-46.

8. Wallace JL, Justine Wu. Emergency Contraception: Knowledge and Attitude of Family Medicine Providers. Family Medicine. 2004;36(6):417-22.

9. Lawrence RE, Rasinki KA, Yoon JD, Curlin FA. Obstetrician-gynecologist physicians' beliefs about emergency contraception: a national survey. Contraception. 2010;82(4):324-30.

10. Oriji VK, Omietimi JE. Knowledge, attitude and practice of emergency contraception among medical doctors in Port Hartcourt. Niger J Clin Pract. 2011;14(4):428-31.

11. Rosie Burton, Wendy Savage. Knowledge and use of postcoital contraception: a survey among health professionals in Tower Hamlets. British Journal of General Practice. 1990;40:326-30.

12. Roy S, Menon S, Sethi NK. Emergegency contraception in reproductive health care: A Technical manual. National Institute of Health and family Welfare. New Delhi, India. 2002:27-28.

13. Sunita TH, Desai RM. Knowledge, attitude and practice of contraception among women attending a tertiary care hospital in India. Int $\mathrm{J}$ Reprod Contracept Obstet Gynecol. 2013;2:172-6.

Cite this article as: Sunil Kumar KS, Hoblidar S. Emergency contraception, a study on knowledge, attitude and practice among gynecologists. Int $\mathbf{J}$ Reprod Contracept Obstet Gynecol 2016;5:198-201. 